\title{
A rapid and inexpensive molecular technique to discriminate the north-eastern Atlantic and Mediterranean Atherina species and its potential applications in ecology and larval identification
}

\author{
Vítor Carvalho Almada ${ }^{1}$, Sara Martins Francisco ${ }^{1 *}$, Inęs Rosa ${ }^{2}$, Vera Domingues ${ }^{1}$, \\ Henrique Cabral ${ }^{3}$, Frederico Almada ${ }^{1}$, Miguel Henriques ${ }^{4}$ \& Joana Robalo ${ }^{1}$ \\ ${ }^{1}$ Eco-Ethology Research Unit, ISPA University Institute, R. Jardim do Tabaco, 34, 1149-041 Lisboa, Portugal; e-mail: \\ sara_francisco@ispa.pt \\ ${ }^{2}$ Departamento de Biologia \& CESAM, Universidade de Aveiro, Campus Universitário de Santiago, 3810-193 Aveiro, \\ Portugal \\ ${ }^{3}$ Departamento de Biologia Animal $\&$ Instituto de Oceanografia, Faculdade de Ciencias da Universidade de Lisboa, R. \\ Ernesto Vasconcelos, 1749-016 Lisboa, Portugal \\ ${ }^{4}$ Parque Natural da Arrábida, Instituto da Conservação da Natureza, Praça da República, 2900, Setúbal, Portugal
}

\begin{abstract}
This note describes a rapid and inexpensive Restriction Fragment Length Polymorphism technique to discriminate all species of Atherina (Pisces: Atherinidae) of the north-eastern Atlantic and the Mediterranean. This technique is based on digestion of a fragment of the $12 \mathrm{~S}$ ribosomal RNA (12SrRNA) gene region of mitochondrial DNA with restriction enzymes that recognize species-specific nucleotide sites. The three currently recognized species in the area, as well as two additional forms awaiting formal description, can be discriminated using a set of four endonucleases. We argue that this simple and fast technique may be of great help in the identification of young stages and in ecological surveys.
\end{abstract}

Key words: Atherina; RFLP; mtDNA

\section{Introduction}

Meristic and morphological diagnoses are almost impossible to perform in very small fish that are more likely to have incomplete scale formation. The identification process is also quite destructive and laborious, as it involves intrusive manipulations of the fish, is rather time consuming and is not applicable when fish are damaged. Thus, rapid and non-destructive methods may prove to be very useful in larval identification and in ecological surveys.

In this respect, species of the genus Atherina provide a good example. They are small and delicate fish that very frequently get damaged during collection. They are important ecological components of inshore, estuarine and lagunar habitats, both as small predators and prey of larger fish and birds (e.g., Bartulovic et al. 2004; Pombo et al. 2005). Often several species are sympatric and their identification relies on detailed inspection and scale counts. For the reason mentioned above, molecular markers seem particularly promising in species identification in this genus.

For several decades, the taxonomy of the genus Atherina (L., 1758) has been controversial due to high intra-specific variability and the overlap of morpholog- ical characters between species. In an extensive review of the Mediterranean sand-smelts, Kiener \& Spillman (1969) recognized three species: Atherina hepsetus (L., 1758), Atherina presbyter (Cuvier, 1829) and Atherina boyeri (Risso, 1810). Atherina hepsetus is restricted to marine conditions in the Mediterranean basin. Its sister species, A. presbyter, occurs in marine conditions along west Europe, North Africa and Macaronesia. Atherina boyeri occurs in small populations in freshwater bodies, estuaries and coastal lagoons along Western Europe and in the Mediterranean, where it was also reported for marine conditions. Subsequent morphological and genetic studies proposed the subdivision of the $A$. boyeri complex in three forms (e.g., Klossa-Kilia et al. 2002; Trabelsi et al. 2002; Astolfi et al. 2005; Francisco et al. 2008, 2011): one marine "punctuated" (spotted on the flanks), another marine "non-punctuated" fish and a third ("also non punctuated") ecologically specialized in brackish and freshwater environments like estuaries, lagoons, etc. There is still much debate on which of these three fishes will retain the name $A$. boyeri and the two other forms still await formal description. Francisco et al. (2011) further confirmed that the three putative forms are as distinct as other "good" species of Atherina, both at the mitochondrial and nuclear level, with

\footnotetext{
* Corresponding author
} 
Table 1. Number of specimens and GenBank accession numbers, for each species analysed. Restriction endonucleases and respective recognition sequence tested in this study, with the position where the sequence is cut (based on the aligned 430 bp dataset).

\begin{tabular}{|c|c|c|c|c|c|c|}
\hline Endonuclease & Recognition sequence & $\begin{array}{c}\text { A. presbyter } \\
N=48\end{array}$ & $\begin{array}{c}\text { A. boyeri } \\
N=101\end{array}$ & $\begin{array}{c}\text { A. hepsetus } \\
\quad N=30\end{array}$ & $\begin{array}{l}\text { Punctuated } \\
\quad N=8\end{array}$ & $\begin{array}{c}\text { Non punctuated } \\
\qquad N=19\end{array}$ \\
\hline Bbv12I & $\mathrm{GDGCH}^{\wedge} \mathrm{C}$ & - & 70 & - & - & - \\
\hline AcoI & $\mathrm{Y}^{\wedge} \mathrm{GGCCR}$ & - & - & 55 & - & - \\
\hline BanI & $\mathrm{G}^{\wedge} \mathrm{GYRCC}$ & - & - & - & - & $212^{*}$ \\
\hline \multirow[t]{2}{*}{ DdeI } & $\mathrm{C}^{\wedge} \mathrm{TNAG}$ & - & - & - & 300 & - \\
\hline & GenBank accession numbers & $\begin{array}{c}\text { AY682895-913; } \\
\text { EF611426-39; } \\
\text { EF618733-7; } \\
\text { HQ176514-6 }\end{array}$ & $\begin{array}{c}\text { AY682874-94; } \\
\text { HQ179501-13; } \\
\text { EU295918-31; } \\
\text { EU295938; } \\
\text { EF611451-94; } \\
\text { AY749053-5 }\end{array}$ & $\begin{array}{l}\text { AY682874-94; } \\
\text { EF618738-49; } \\
\text { EF611447-50; } \\
\text { AY749048-50 }\end{array}$ & $\begin{array}{l}\text { EF611503-9; } \\
\text { AY749051-2 }\end{array}$ & EF611495-502 \\
\hline
\end{tabular}

Explanations: $N$ - number of specimens, ${ }^{*}$ one sequence not cut due to mutation at the recognition sequence.

ecological differences between marine and non-marine fish corresponding to distinct clades.

In this note we amplify a fragment of the $12 \mathrm{~S}$ ribosomal RNA (12SrRNA) gene region of mitochondrial DNA, successfully used for multiple fish families (e.g., Gobiesocidae, Tripterygiidae, Soleidae, Blennidae). We compared sequences of a fragment of the $12 \mathrm{~S}$ mitochondrial ribosomal DNA from all north-eastern Atlantic and Mediterranean Atherina species: A. presbyter, A. hepsetus, A. boyeri plus the marine "punctuated" and "non-punctuated" forms. Based on the results of this analysis we developed a fast screening species-specific Restriction Fragment Length Polymorphism (RFLP) technique that efficiently discriminates between species. This technique may be applicable to very young fish and in non-destructive ecological surveys, particularly in brackish waters, where species with different salinity pressures are commonly sympatric.

\section{Material and methods}

All 12S rDNA sequences of Atherina from the north-eastern Atlantic and the Mediterranean available in GenBank were retrieved and included in the present analysis (see Table 1 ). Additionally, forty specimens (19 A. presbyter and 21 A. boyeri) were used to amplify and sequence a fragment of the $12 \mathrm{~S}$ rDNA. Total genomic DNA was extracted from fin rays following the protocol of Sambrook et al. (1989). A fragment of $430 \mathrm{bp}$ of the $12 \mathrm{~S}$ rDNA was amplified using the primer pair 12SFor (5'-AAC TGG GAT TAG ATA CCC CAC-3') and 12SRev (5'-GGG AGA GTG ACG GGC GGT GTG3') first described in Henriques et al. (2002). PCR amplifications were performed in $20 \mu \mathrm{l}$ total volume, with approximately $20 \mathrm{ng}$ total DNA and 1 unit Taq DNA polymerase (Fermentas). The final concentrations were $2.5 \mathrm{mM} \mathrm{MgCl}_{2}$, $0.25 \mathrm{mM}$ each dNTP, $0.5 \mu \mathrm{M}$ each primer and $1 \mathrm{x}$ buffer supplied by the manufacturer.

The amplifications in a Biorad Gene-Cycler ${ }^{\mathrm{TM}}$ for 12SFor-12SRev consisted in $2 \mathrm{~min}$ at $92^{\circ} \mathrm{C}, 2 \mathrm{~min}$ at $91^{\circ} \mathrm{C}$, and 30 cycles of $1 \mathrm{~min}$ at $94^{\circ} \mathrm{C}, 1 \mathrm{~min}$ at $55^{\circ} \mathrm{C}$ and $1 \mathrm{~min}$ at $72^{\circ} \mathrm{C}$. Finally these products were kept at $72^{\circ} \mathrm{C}$ for $10 \mathrm{~min}$.

PCR products were purified with the GFX PCR DNA purification kit (Amersham-Pharmacia), following the recommendations of the manufacturer. Automatic sequencing of purified PCR products was performed in a CEQ 2000 XL, Beckman Coulter.

All sequences were deposited in GenBank and voucher specimens were deposited in the collections of ISPA (University Institute of Psychological, Social and Life Sciences, Lisbon, Portugal). The $430 \mathrm{bp}$ fragment obtained was homologous to the remaining sequences retrieved from GenBank. All sequences (both those retrieved from GenBank and those produced for the present study) were aligned using ClustalX (Thompson 1997). For the $430 \mathrm{bp}$ fragment for which our sequences and those available in GenBank showed unambiguous and complete alignment we searched for restriction enzymes that fulfilled two criteria: 1) they should recognize specifically the DNA of a species; 2) they should yield consistent results with all the sequences of the species for which they were candidates. The free online tool WatCut (http://watcut.uwaterloo.ca/watcut/watcut/template.php) was used to search for restriction enzyme cleavage sites in all the $12 \mathrm{~S}$ sequences.

The best candidates were used to digest our PCR products to verify that the sequences cut and sizes of the restriction fragments corresponded to what was expected from the results of WatCut. PCR products were digested according to the manufacturer's recommendations (Fermentas) and digested products were analysed through electrophoresis in $3 \%$ agarose gel stained with ethidium bromide $(0.5 \mu \mathrm{g}$ $\left.\mathrm{ml}^{-1}\right)$.

\section{Results}

Using the $430 \mathrm{bp}$ sequences of 206 Atherina specimens, all forms of Atherina from the north-eastern Atlantic and the Mediterranean were specifically and unambiguously discriminated using a set of four endonucleases (Table 1, Fig. 1). Atherina hepsetus may be discriminated from all the other species by digestion with Acol. Endonuclease Ddel digested 'punctuated' forms only, while Banl cut exclusively 'non-punctuated' specimens. For this last form, one of the sequences (Accession number EF611506) was not cut by BanI or by any of the used endonucleases, due to a mutation at the site recognised by the restriction enzyme. Restriction enzyme Bbv12I cut $A$. boyeri sequences but not any of the other species. None of the restriction enzymes tested recognize exclusively $A$. presbyter nucleotide sequences. 


\section{A. hepsetus}

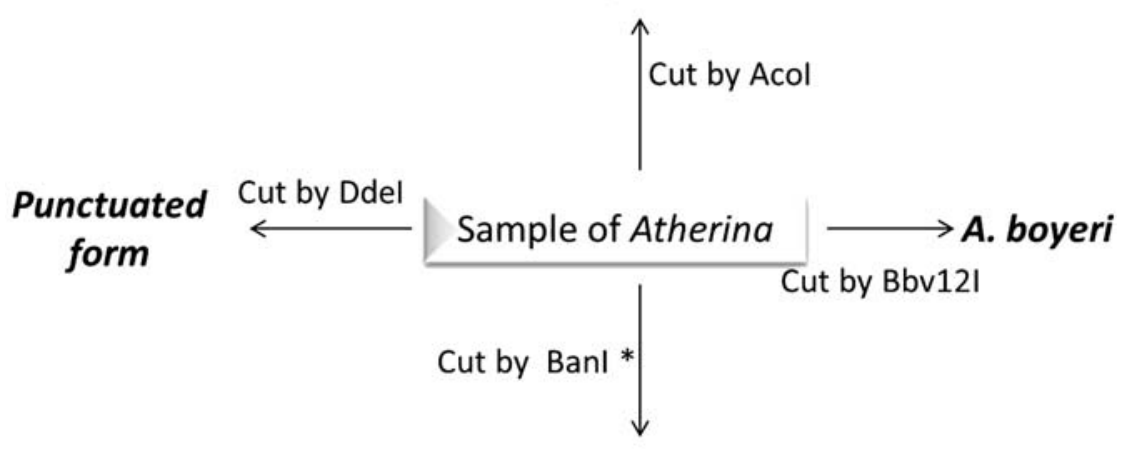

Non punctuated form

Fig. 1. Schematic representation of the application of our molecular screening method to the identification of Atlantic and Mediterranean Atherina species. *One of the analysed sequences of the non-punctuated form was not cut due to a mutation at the site recognised by the restriction endonuclease.

However, A. presbyter can be identified by absence of digestion with enzymes from the four groups described above.

\section{Discussion}

We developed a fast and easy method of species identification based on the digestion of a $12 \mathrm{~S}$ rDNA fragment with restriction endonucleases to accurately discriminate Atherina species in the North Atlantic and Mediterranean. The use of a slowly evolving DNA marker, yielding few haplotypes in each species, but allowing the detection of differences between species, is ideal for the development of discriminating techniques based on digestion by restriction enzymes and electrophoresis. Since sequencing is one of the most expensive components of DNA studies, situations when PCR followed by the use of one or a few restriction enzymes are reliably applicable, make molecular screening a very useful tool. The technique described in this paper is much cheaper than sequencing and may be applied to DNA extracted from small fin clips, larvae and to very small individuals (difficult to analyse morphologically). Thus, this method is very effective both for the identification of small fish, and for non-destructive screening of larger specimens. Furthermore, it may be also useful to identify fish that have been damaged in the fishing process, a situation that occurs easily with the delicate bodies of the members of the genus Atherina. In the future, the method will be tested on fish remains extracted from stomach contents or other fish or birds with the necessary adaptations. Sandsmelts are small fish but so abundant in lagoons, estuaries and near rocky shores that they are assumed to represent an important component of the diet of marine birds and fish, while at the same time being consumers of a wide spectrum of small invertebrates (e.g., Bartulovic et al. 2004; Pombo et al. 2005). Thus, surveys of their populations are important in studies of inshore, estuarine and lagunar ecosystems.

\section{Acknowledgements}

The authors are grateful to Dr. B. Castro and Prof. F.J. Mendes Gonçalves. The authors also thank P. Carpi and F. Carlos for their help in the laboratory. This study was funded by the European Science Foundation's MarinERA project "Marine phylogeographic structuring during climate change: the signature of leading and rear edge of range shifting populations" and by the Eco-Ethology Research Unit (331/94) pluriannual financing programme (Fundação para a Ciência e Tecnologia, partially FEDER funded). S. Martins Francisco (SFRH/BD/12653/2003) and F. Almada (SFRH/BPD/63170/2009) research was supported by grants from FCT. The authors declare that any experiments comply with the current laws of the country in which they were performed.

\section{References}

Astolfi L., Dupanlouop I., Rossi R., Bisol P.M., Faure E. \& Congiu L. 2005. Mitochondrial variability of sand smelt (Atherina boyeri, Risso, 1810) populations from North Mediterranean coastal lagoons. Mar. Ecol. Prog. Ser. 297: 233-243. DOI: $10.3354 /$ meps297233

Bartulovic V., Lucic D., Conides A., Glamuzina B., Dulcic J., Hafner D. \& Batistic M. 2004. Food of sand smelt, Atherina boyeri Risso, 1810 (Pisces: Atherinidae) in the estuary of the Mala Neretva River (middle-eastern Adriatic, Croatia). Sci. Mar. 68 (4): 597-603.

Francisco S.M., Congiu L., Sefanni S., Castilho R., Brito A., Ivanova P.P., Levy A., Cabral H., Kilias G., Doadrio I. \& Almada V.C. 2008. Phylogenetic relationships of the North-eastern Atlantic and Mediterranean forms of Atherina (Pisces, Atherinidae). Mol. Phylogenet. Evol. 48 (2): 782788. DOI: $10.1016 / \mathrm{j} . y m p e v .2007 .12 .009$

Francisco S.M., Congiu L., von der Heyden S. \& Almada V.C. 2011. Multilocus phylogenetic analysis of the genus Atherina (Pisces: Atherinidae). Mol. Phylogenet. Evol. 61 (1): 71-78. DOI: $10.1016 /$ j.ympev.2011.06.002

Henriques M., Lourenço R., Almada F., Calado G., Gonçalves D., Guillemaud T., Cancela M.L. \& Almada V.C. 2002. A revision of the status Lepadogaster lepadogaster (Teleostei: Gobiesocidae): sympatric subspecies or a long misunderstood blend of species? Biol. J. Linn. Soc. 76 (3): 327-338. DOI: 10.1111/j.1095-8312.2002.tb01700.x

Kiener A. \& Spillman C.-J. 1969. Contribution à l'étude systématique et écologique des athérines des côtes françaises. Mém. Mus. Nat. Hist. Natur. Ser. A Zool. 60 (2): 33-74. 74 pp. 
Klossa-Kilia E., Prassa M., Papasotiropoulos V., Alahiotis S. \& Kilias G. 2002. Mitochondrial DNA diversity in Atherina boyeri populations as determined by RFLP analysis of three mtDNA segments. Heredity 89 (Part 5): 363-370. DOI: 10.1038/sj.hdy. 6800144

Pombo L., Elliott M. \& Rebelo J.E. 2005. Ecology, age and growth of Atherina boyeri and Atherina presbyter in the Ria de Aveiro, Portugal. Cybium 29 (1): 47-55.

Sambrook E., Fritsch F. \& Maniatis T. 1989. Molecular Cloning: A Laboratory Manual. Cold Spring Harbour Laboratory Press, 2 ${ }^{\text {nd }}$ Ed., New York, Vol. 1, 2, 3, 1659 pp. ISBN: 0879693096, 9780879693091
Thompson J.D., Gibson T.J., Plewniak F., Jeanmougin F. \& Higgins D.G. 1997. The ClustalX windows interface: flexible strategies for multiple sequence alignment aided by quality analysis tools. Nucleic Acids Res. 25 (24): 4876-4882. DOI: $10.1093 / \mathrm{nar} / 25.24 .4876$

Trabelsi M., Gilles A., Fleury C., Mâamouri F., Quignard J.P. \& Faure E. 2002. Atherina punctata and Atherina lagunae (Pisces, Atherinidae), new species in the Mediterranean Sea. 2. Molecular investigations of three Atherinid species. C. R. Biol. 325 (11): 1119-1128. DOI: 10.1016/S16310691(02)01529-9

Received February 29, 2012 Accepted June 15, 2012 